MICHAEL KNÜPPEL

Liaocheng University

michaelknueppel@gmx.net

\title{
FURTHER REMARKS ON CHINESE ĀHŌNG 阿氬
}

Keywords: Hui Muslims, title/address, Persian loanword, Muslim clerics

\begin{abstract}
In the article the author once again deals with the title/address for Hui Muslim imāms, $\bar{A} h \bar{n}$ g (阿言), - a topic about which he already gave some information in a miscella published in Knüppel (2020). To this some further details on historical attempts of etymology are given in the text presented here.
\end{abstract}

When the author occasionally commented on the etymology of the Chinese title of imāms in the "Middle Kingdom", Āhōng (阿言) (Knüppel 2020) in this journal, he initially neglected to point out that the word was used within Hui-Muslim communities (especially in Western China, or more precisely, within the communities in the provinces of Níngxià, Qīnghǎi and Gānsù) and is sometimes used as a kind of honorary title for religiously educated non-theologians (Stewart 2018: 74-101). This additional remark would of course not justify an addendum to the miscellany in question. Therefore, on the occasion of an etymological-historical contribution by the author, there appeared a suggestion on the part of a colleague who was interested in "one or the other episode" from the history of the etymology of the lexical item (beyond, for example, considerations such as the ones about -kiund as a correspondence to $k \bar{a} v a n d$, which in turn was interpreted as the short form of kodavvand ${ }^{1}$ ). The author would like to respond to this in the form of a reflection on the subject by Ámin(ius) Vámbéry (1832-1913) (whose life and work is another main research focus of the author).

1 Algar (1985: 731) - according to Radloff (1893, col. 135), who provides some evidence for axyн (Tar., Kas., Ad.), with the meaning '[...] der Obermulla, Achun [...]', ахунд (Dsch.) and also for акын (Bar., Tob.) 'Ober-Mulla' (Radloff 1893, col. 109), but only traced the term back to Persian. 
In one of the early contributions of the exceptional Hungarian-Jewish scholar and co-founder of Turkology, he gave the following explanation of the term in a commentary on a Chinese-Tatar (= Uyghur) text he had edited:

Achond, ein Titel, in der chinesischen Tatarei dem Worte Herr gleichbedeutend, wird in Persien nur der Priesterklasse und den Gelehrten gegeben. Dem Ursprunge nach scheint es mir halb türkisch, halb persisch, zusammengezogen aus aga chonde, belesener Herr.

Achond, a title equivalent to the word Lord in Chinese Tatary, is given only to the priestly class and scholars in Persia. According to its origins it seems to me half Turkish, half Persian, drawn from aga chonde, well-read gentleman.' (Vámbéry 1865: 301)

In the accompanying note also:

Die ursprüngliche Bedeutung von Achond wie von Aga (finn. Uko, der Alte, Aka, die Alte) scheint die des pers. بير (شيخ zu seyn; s. Neumann [...], Mordtmann [...]. Im ältern Osmanischen kommt noch Achy اختير als Ehrentitel von Gelehrten vor, [...]

'The original meaning of Achond as of Aga (Finn Uko, the old man, Aka, the old woman) seems to be that of Pers. يرير of Arab. to be cf. Neumann [...], Mordtmann [...]. In the older Ottoman language, Achy آخ still appears as an honorary title for scholars.' (Vámbéry 1865, note 1)

If we now consider the explanations provided by Neumann (those of Mordtmann 1862: 53-54, which deal with اغ 'older brother', can be neglected at this point), there are some interesting remarks, naturally owed to the state of research of that time:

[...] und zwar durch einige bekehrte Chinesen, wie Krang Afa und Tsai Ako, oder Bruder Tsai, der erste Chinese, welchen Morrison (1814) zu taufen das Glück hatte. '[...] by some converted Chinese, such as Krang Afa and Tsai Ako, or Brother Tsai, the first Chinese, whom Morrison (1814) was lucky enough to baptize.' (Neumann 1847: 218)

and especially in the accompanying note:

Ako ist ein Wort, welches aus dem Mandschu in's Chinesische übergegangen ist; Ahun heißt ein älterer Bruder in der Sprache der regierenden Familie. Es ist auffallend, dass dies, soviel mir bekannt, in den Wörterbüchern der Missionare nicht bemerkt wurde.

'Ako is a word that has passed from Manchu to Chinese; Ahun is an older brother's name in the language of the ruling family. It is striking that this, as far as I know, was not noticed in the dictionaries of the missionaries.' (Neumann 1847, note 2)

Manžu ahun here means ahūn 'elder brother' and 'older ([...] a male)' (Norman 2013, col. 7a) - a connection to the name of the "first" Chinese Protestant convert Tsai Ako (1788-1818) or the idea that his name has something to do with the manžu-term, to which Vámbéry was indirectly referring, but not really based his explanation on (i.e. only on the meaning of the word), is really doubtful. Behind the "Tsai Ako", 
which at first glance appears somewhat cryptic, we find the first Chinese who supposedly converted to Protestantism and was baptized by the Scottish missionary and lexicographer Robert Morrison (1782-1834). ${ }^{2}$ His name may have been Cài Gāo (蔡高), ${ }^{3}$ which (apart from the family name) is not entirely clear and is notated in the literature as differently as it has been interpreted. The main problem is that the name in records and descriptions of Western missionaries is always given in Latin transcriptions: Tsae A-fo (Morrison 1839: 343, 439) and Tsae Ko - but also in the variants that were finally taken up by Neumann: Tsai A-Ko ( Chai Agao) (Melton 2005, col. 387 b), Tsae A-Ko (Morrison 1839: 408 f), Tsae Ako (Morrison 1839: 531; Hallihan 2008, col. 21 b; on the different spellings of the name (and the evidence for these), cf. Seitz 2013: 166). Not entirely uninteresting for the subject is perhaps the fact, also mentioned by Morrison, that Cài Gāo had an older brother named A-yun (Ayun) (Morrison 1839: 357, 531). Additional confusion may have arisen here - after all, Neumann does not provide any information on the works from which he drew his information on manžu ahun and Chinese ako (he must have used one or the other report or description of Morrison). In fact, however, a connection with Manžu ahun ahūn or with the Muslim title Āhōng can hardly be made here - apart from the fact that Cài Gāo was neither a Manžu nor a Muslim, but a Cantonese.

It can be determined without any doubt that the examples given here for endeavours from the history of the etymology of the word $\bar{A} h \bar{n}$ ng are only an excerpt from a significantly wider field.

Obviously, today whenever such a look is directed at the etymologization efforts of our predecessors, one must be aware of the fact that they were hesitant and sometimes not always cautious of different approaches to several languages. Languages, the research of which was often still in its infancy, and this happened at a time, when some orientalist disciplines were not yet fully developed and were sometimes still in their "formative phases".

\section{References}

Algar H. 1985. Āk̄ūnd. - Encyclopaedia Iranica. [vol. 1.7]. London: Routledge \& Kegan Paul: 731-732.

Hallihan C.P. 2008. Robert Morrison. Bible translator of China, 1782-1834. - Quarterly Report [of the] Trinitarian Bible Society 585: 11-28.

Knüppel M. 2020. On Chinese Āhōng 阿言. - Studia Linguistica Universitatis Iagellonicae Cracoviensis 137: 83-84.

Melton J.G. 2005. Encyclopedia of Protestantism. New York: Facts on File.

Mordtmann A.D. 1862. Erklärung der Keilschriften zweier Gattung. - ZDMG 16: 1-126.

Morrison E. (ed.). 1839. Memoirs of the life and labours of Robert Morrison, D.D. [vol. 1]. London: Longman, Orme, Brown, Green, and Longmans.

Neumann K.F. 1847. Die Sinologen und ihre Werke. - ZDMG 1: 217-237.

On R. Morrison, cf. Morrison (1839), Townsend (1890) and Rennstich (1993).

3 Cf. Seitz (2013: 165-171). 
Norman J. 2013. A comprehensive Manchu-English dictionary. [= Harvard-Yenching Institute Monograph Series 85]. Harvard: Harvard University Asia Center.

Radloff W. 1893. Versuch eines Wörterbuches der Türk-Dialecte. [vol. 1]. St. Petersburg: Imperatorskaya Akademiya Nauk.

Rennstich K.W. 1993. Morrison, Robert. - BBKL 6: coll. 145-146.

Seitz J.A. 2013. Is conversion to Christianity pantheon theocide? Fragility and durability in early diasporic Chinese protestantism. - Young R.F., Seitz J.A. (eds.). Asia in the making of Christianity. Conversion, agency, and indigeneity, 1600s to the present. [= Social Sciences in Asia 35]. Boston, Leiden: BRILL: 163-187.

Stewart A.B. 2018. Chinese Muslims and the Global Ummah. Islamic revival and ethnic identity among the Hui of Qinghai Province. [= Routledge Contemporary China Series]. New York, London: Routledge.

Townsend W. 1890. Robert Morrison - the pioneer of Chinese missions. London: S. W. Partridge \& co.

Vámbéry H. 1865. Ein chinesisch-tatarischer Originalbrief, übersetzt und mit Anmerkungen begleitet. - ZDMG 19: 297-302. 